\title{
Study on Land Use/Cover Change in Khajuri Drain (Nala) in Mirzapur Region, Uttar Pradesh, India
}

\author{
Surendra Kumar
}

Research Scholar (Department of Geography), Veer Bahadur Singh Purwanchal University, Jaunpur (U. P.), India

\begin{abstract}
The role of drains (Nala) is important in the structural unit of the drainage system. The contribution of the drain (Nala) of that area is important in the development and flow pattern of any river. 'Khajuri Nala' is located in district Mirzapur (U. P.), the origin of this drains (Nala) is form the 'lower Khajuri Dam' Near "Barkachhakalan" located in the central part of district Mirzapur. This drains (Nala) flowing in the North - East direction from its place of origin, merges with the river Holy Ganga, near Ratambo Chauhanpatti belt. Khajuri Nala is also, known as Small River in local places. Water flow's in this drain for 12 month of the years. The average length of this drain is 20 miles (32.187 KM). This drain (Nala) cover an area of 27 miles (70 KM) of its range. This drain has important utility in local area, with the help of this drain (Nala) Irrigation work is mostly done in the area of this drain. Due to which this area is always green and the field of crops is also high.
\end{abstract}

\section{Introduction}

The role of drain (Nala) is important in the morphology of any river, the structure of the 'beds and edge' and visual appearance, the change in the Morphology of river upstream is due to the water flow of large level Rivulets. Generally a network of many small and big drains exists in the morphological structure of all river's.

The origin of 'Khajuri Nala' is mainly considered to be the 'lower Khajuri Dam' but this drain (Nala) has been flowing before the construction of Dam and the source of this drain (Nala) HarraiNala. Due to the construction of the 'lower Khajuri Dam' in 1962, this drain was named KajuriNala. The main reason for this being the water flow source of the drain (Nala) from the 'Lower Khajuri Dam' itself. 'Khajuri Dam' is spread over 7280 hectares of land and the average capacity of this Dam is 37.834 MCM. Water is being supplied from 'Khajuri Dam' to 'Rajiv Gandhi South Campus - Mirzapur" a branch of "Banaras Hindu University (BHU) " located on the 'Barkachhakalan' plateau.

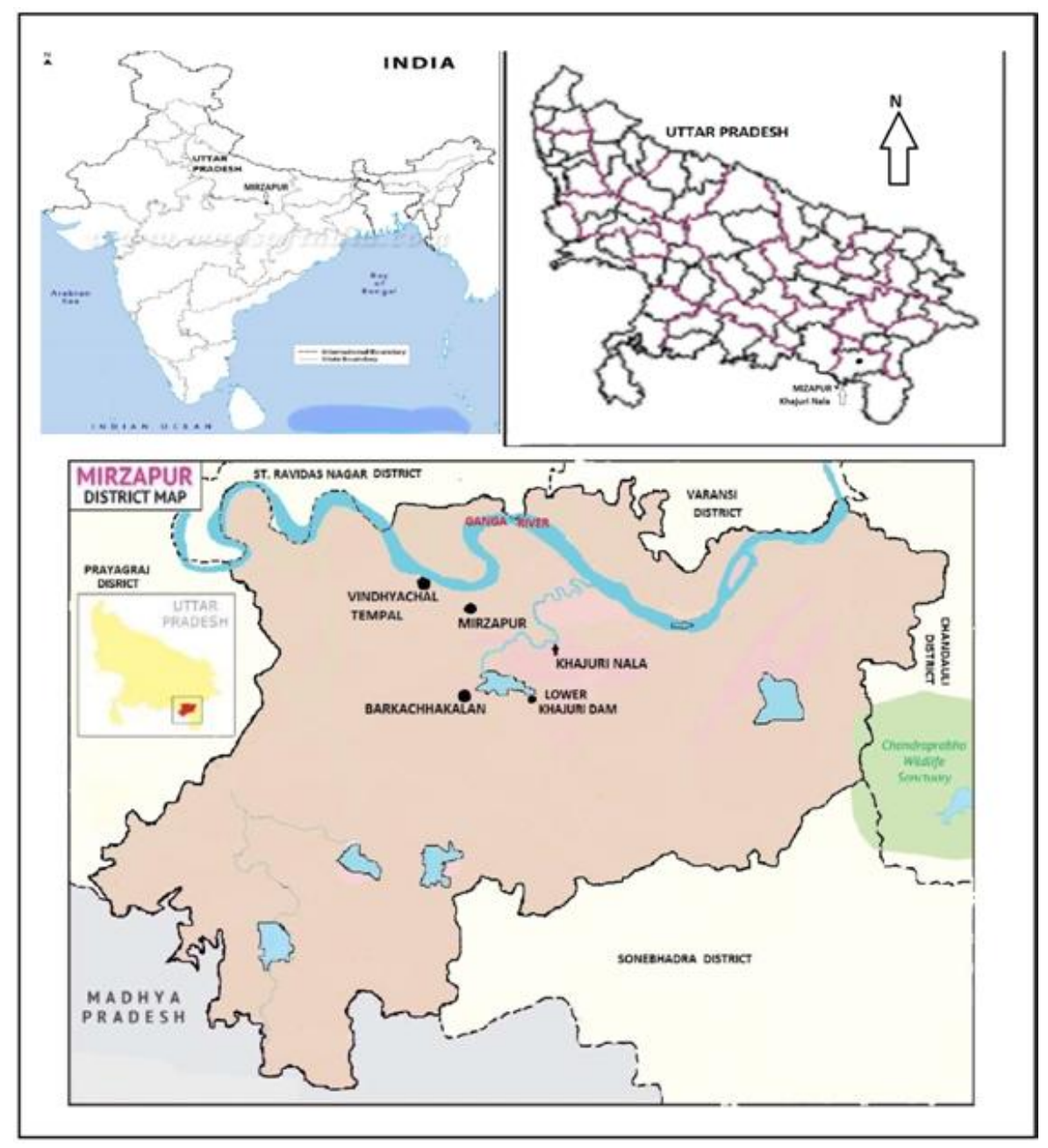

Volume 9 Issue 2, 2022

www.jissr.net 


\section{Place of Origin}

'Khajuri Nala' originates from the 'Lower Khajuri Dam' at a place called 'Barkachhankalan' at $25^{\circ} 4^{\mathrm{I}} 49^{\mathrm{II}}$ North Latitude and $82^{\circ} 36^{\mathrm{I}} 18^{\mathrm{II}}$ East longitude. The length of 'Khajuri Nala' 20 miles (32.187 KM).

This drain (Nala) flowing in the North - East direction from its place of origin, merges with the 'Holy Ganga river' at a place called "Ratambo - Chauhanpatti" at $25^{0} 10^{\mathrm{I}} 19^{\mathrm{II}}$ North and $82^{0} 42^{\mathrm{I}} 4^{\mathrm{II}}$ East.

\section{Drainage pattern}

'Khajuri Nala' has a total of 14 Stream Order and 73 Stream Number and total average length of the stream is $75 \mathrm{KM}$. The length of the stream between Khajuri Nala is 11.928 $\mathrm{KM}$ and the ratio of the length of the stream is 11.076 , there are mainly 05 small tributaries of this drain (Nala), which meet in Khajuri Nala.

\section{Soil Structure}

In the area of Khajuri Nala, mainly - pathari soil, clay soil, sand loam soil and leterite soil's pre - dominate.

\section{Temperature}

Temperature condition in the vicinity (Zone) of Khajuri Nala -

Maximum Temperature $-45^{\circ} \mathrm{C}$

Minimum Temperature $-08^{0} \mathrm{C}$

Average Temperature $-27{ }^{\circ} \mathrm{C}$
Drainage pattern of 'KHAJURI NALA' District - Mirzapur (U. P.)

\begin{tabular}{|c|c|c|c|c|c|}
\hline $\begin{array}{c}\text { Stream } \\
\text { Order }\end{array}$ & $\begin{array}{c}\text { Number } \\
\text { of } \\
\text { Stream }\end{array}$ & $\begin{array}{c}\text { Stream of } \\
\text { Length } \\
(\mathrm{KM}) \text { Lu }\end{array}$ & $\begin{array}{c}\text { Mean } \\
\text { Stream } \\
\text { Length } \\
(\text { Lsm })\end{array}$ & $\begin{array}{c}\text { Stream Length } \\
\text { Ratio (LR) }\end{array}$ & $\begin{array}{c}\text { Bifurcation } \\
(\mathrm{Rb})\end{array}$ \\
\hline 01 & 25 & 37.5 & 1.500 & $\ldots \ldots \ldots \ldots \ldots \ldots \ldots \ldots \ldots \ldots$ & $\ldots \ldots \ldots \ldots$ \\
\hline 02 & 05 & 5 & 1.000 & 0.134 & 0.200 \\
\hline 03 & 07 & 4.5 & 0.643 & 0.900 & 1.400 \\
\hline 04 & 04 & 4.5 & 1.125 & 1.000 & 0.571 \\
\hline 05 & 05 & 3 & 0.600 & 0.667 & 1.250 \\
\hline 06 & 04 & 2.8 & 0.700 & 0.934 & 0.800 \\
\hline 07 & 04 & 2.6 & 0.650 & 0.929 & 1.000 \\
\hline 08 & 04 & 2.5 & 0.625 & 0.962 & 1.000 \\
\hline 09 & 03 & 2.5 & 0.834 & 1.000 & 0.750 \\
\hline 10 & 03 & 2.5 & 0.834 & 1.000 & 1.000 \\
\hline 11 & 02 & 2.5 & 1.250 & 1.000 & 0.667 \\
\hline 12 & 03 & 2 & 0.667 & 0.800 & 1.500 \\
\hline 13 & 02 & 1.5 & 0.750 & 0.750 & 0.667 \\
\hline 14 & 02 & 1.5 & 0.750 & 1.000 & 1.000 \\
\hline Total & 73 & 74.9 & 11.928 & 11.076 & 11.805 \\
\hline & \multicolumn{2}{|c|}{ Average } & 0.918 & 0.852 & 0.908 \\
\hline
\end{tabular}

Morphometric Parameter

Mean Stream Length $(\mathrm{Lsm})=\mathrm{Lu} / \mathrm{Nu}-$ Strahlar (1964).

Stream Length Ratio (RL) = Lu/LU - 1 - Hoton (1945).

Bifurcation Ratio $=\mathrm{Nu} / \mathrm{Nu}+1-$ Schumn (1956).

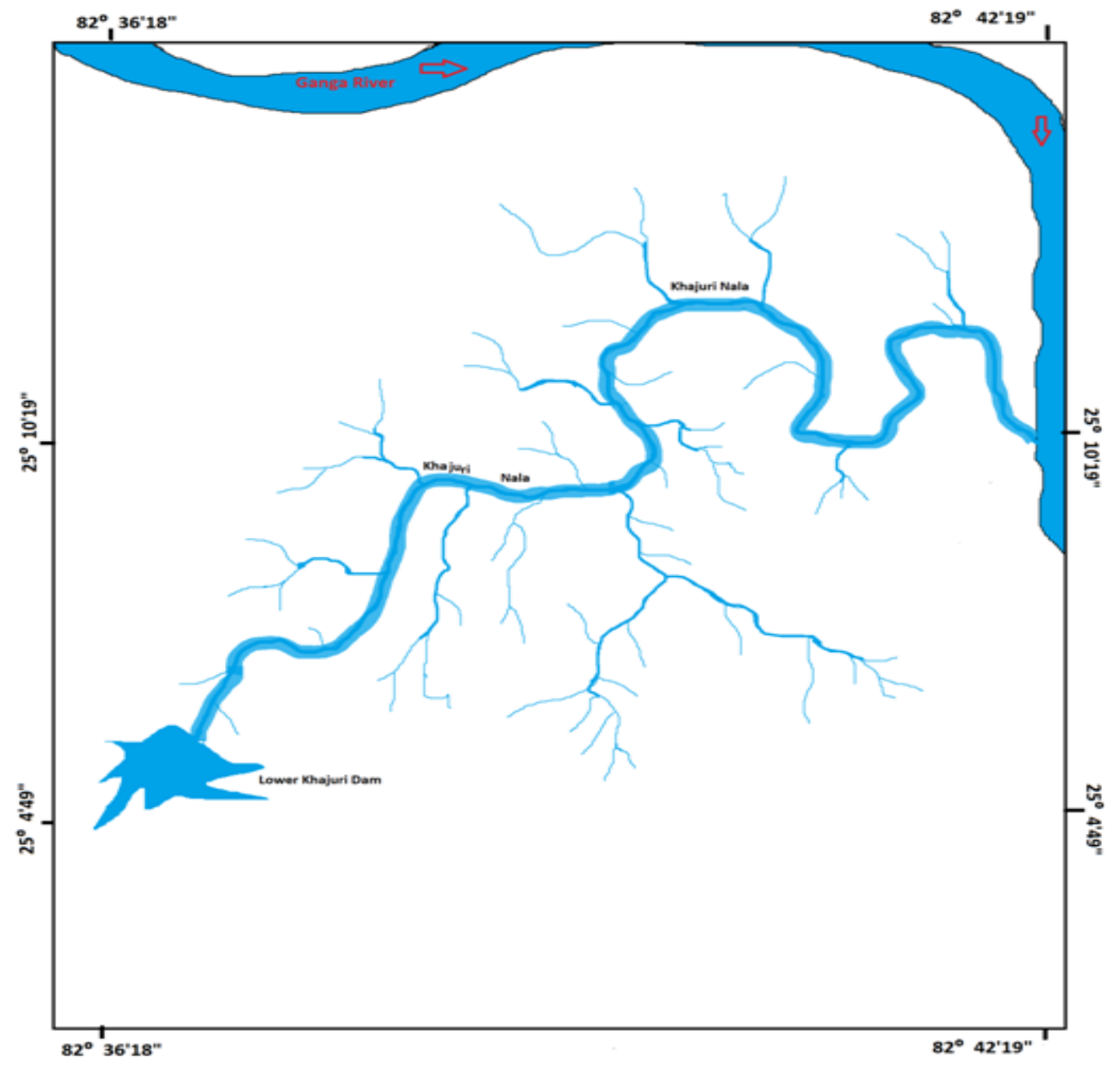




\section{Khajuri Nala Review}

Khajuri Nala originates from the 'Lower Khajuri Dam' at a height of 100 meters in the plateau part of "Vindhya Mountain Range". The main source of water flow in this drain (Nala) is from the water present in the Khajuri Dam. Khajuri Nala covers an average of $70 \mathrm{KM}^{2}$ in its flow area.

The average green field is visible in the area of Khajuri Nala, main reason for this is that there is always water flow in this drain (Nala), which reflects the greenery around the drain/Nala. Fertile soils are found in abundance in the area of seasonal crops such as - wheat, paddy, jau, bajara, gram, peas, and oilseeds, crops, along with the production of fruits and vegetables in abundance is done in. This Nala compatibility of Natural beauty. Constructed to collect the water flow of this drain (Nala) at some place, than this direct flowing water will flow intermittently, which will lead to Agricultural work and fisheries and animal husbandry, Businesses will have the necessary water supply. Due to the collection of water of 'Khajuri Nala'. Human community and trees along with animal and birds will also get the necessary water and the ground water level will also remain normal.

The $\mathrm{PH}$ of the water of this Nala is up to $5-7$

\section{Conclusion}

The Khajuri Nala originates from the 'Khajuri Dam' and flow in the North - East direction and merges with the 'Holy Ganga river'. There is always water flowing in this drain (Nala). Due to which it is called as a small river by the local people, but at different place it is known by different names which remains associated with the local names. This Nala irrigates an average of 7000 hectares of land. There is always average of greenery in the vicinity (zone) of this drain. This Nala is very useful at the local level, whose water helps in Agricultural work.

\section{References}

[1] Topo Sheets No - $63 \mathrm{k} / 12$.

[2] Lal D. S., Climatology \& Oceanography, Shardapustak Bhawan Allahabad, $1^{\text {st }}$ Edition 2013.

[3] Singh Savindra, Geomorphology, Vashundhara Publication Gorakhpur, $6^{\text {th }}$ Edition 2011, PP.327 - 342.

[4] Husain Majid\& Singh Ramesh, Indian Geography, Tata MvGrow Hill Education Private Limited, New Delhi, $1^{\text {st }}$ Edition 2009. PP.3.1 - 3.20.

[5] Goh Cheng Leong, Gillian C. Morgan, Human and Economic Geography, Oxford University Press, $2^{\text {nd }}$ Edition 1982.

[6] Singh L. R., Fundamental of Practical Geography, Sharda Pustak Bhawan Allahabad, $1^{\text {st }}$ Edition 2011, PP. $240-245$. 